\title{
LATE POSTOPERATIVE FOLLOW-UP OF PATIENTS UNDERGOING SUBTOTAL SPLENECTOMY
}

\author{
Andy Petroianu, Vivian Resende, and Rodrigo Gomes da Silva
}

Petroianu A, Resende V, Silva RG da. Late postoperative follow-up of patients undergoing subtotal splenectomy. Clinics. 2005;60(6):473-8.

PURPOSE: Over the past 21 years, we have performed more than 200 subtotal splenectomies, in which the upper splenic pole vascularized only by the gastrosplenic pole vascularized only by the gastrosplenic vessels is preserved, to treat different pathologic conditions. A meticulous follow-up of the postoperative results of this procedure is of fundamental importance.

METHODS: All patients undergoing subtotal splenectomy were invited to be reviewed. A total of 86 patients who had undergone surgery 1 to 20 years ago were gathered; the surgical procedure was performed for one of the following conditions: portal hypertension due to schistosomiasis $(n=43)$, trauma $(n=31)$, Gaucher's disease $(n=4)$, myeloid hepatosplenomegaly due to myelofibrosis $(n$ $=3$ ), splenomegalic retarded growth and sexual development $(n=2)$, severe pain due to splenic ischemia $(n=2)$ and pancreatic cystadenoma $(\mathrm{n}=1)$. Patients underwent a hematologic exam, an immunologic assessment, abdominal ultrasonography, computed tomography, scintigraphy and endoscopy.

RESULTS: Increased white blood cell count and platelets were the only hematological abnormalities. No immunologic deficit was found. Esophageal varices were still present in patients who underwent surgery because of portal hyperension although without rebleeding. The ultrasound, tomography and scintigraphy exams confirmed the presence of functional splenic remnants without significant size alteration.

CONCLUSIONS: Subtotal splenectomy seems to be a safe procedure that can be useful in treating conditions involving the spleen. The functions of the splenic remnants are preserved during long periods of time.

KEYWORDS: Partial splenectomy. Subtotal splenectomy. Spleen. Splenic preservation. Postoperative.

Our studies relating to subtotal splenectomy preserving the upper pole vascularized by the splenogastric vessels began in 1979. After five years of experimental investigations in mice, rats, rabbits, cats, dogs and pigs, we were authorized by our Institution to operate on patients with portal hypertension due to schistosomiasis and previous variceal bleeding, and later extending to other diseases. ${ }^{1-9}$

In an attempt to preserve the splenic function, we maintained the upper splenic pole (subtotal splenectomy). Previously we had combined this procedure with a splenorenal shunt. ${ }^{10-13}$ In the presence of hepatic failure, cardiopulmo-

Afla Institute of Gastroenterology, Hospital das Clínicas, Federal University of Minas Gerais (UFMG) - Belo Horizonte/MG, Brazil.

Email: petroian@medicina.ufmg.br

Received for publication on June 21, 2005.

Accepted for publication on September 19, 2005. nary congestive dysfunction or encephalopathy, especially in patients over 40 years of age, we combine the subtotal splenectomy with external portal variceal disconnection and suture gastric and esophageal varices, through an anterior gastrotomy. ${ }^{14}$ We find this option better than a portal systemic shunt.

Subtotal splenectomy was also performed in patients with Gaucher's disease in which giant splenomegaly caused abdominal discomfort, respiratory distress and walking difficulties. ${ }^{15,16}$ A total splenectomy in this disease frequently causes liver enlargement and bone fractures due to deposition of glucocerebroside. ${ }^{17-20}$ Lethal infection is another complication that may follow total splenectomy. ${ }^{20}$ To avoid this complication, partial splenectomy, preserving the splenic pedicle has been proposed. ${ }^{17,18}$ However, several reports have described splenic remnant enlargement, leading 
to recurrent hypersplenism. ${ }^{19,20}$ The maintenance of the upper pole vascularized by the splenogastric vessels potentially avoids some of those complications and does not result in spleen enlargement. ${ }^{15,21,22}$

Myeloid hepatosplenomegaly due to myelofibrosis is another disease that may induce an extraordinary enlargement of the spleen. ${ }^{23}$ The giant spleen leads not only to the same discomfort similar to that described in Gaucher's disease, but also to severe hematological complications. ${ }^{24-26}$ Even though total splenectomy may be helpful in myeloid hepatosplenomegaly this procedure results in great morbidity and mortality. ${ }^{23-28}$ Postoperative massive liver enlargement and rupture due to myeloid hepatomegaly, infections and bleeding are the most frequent complications of total splenectomy. ${ }^{24,26-30}$ Splenic artery ligation and partial splenectomy with preservation of the splenic pedicle are only palliative, since symptoms and splenic enlargement usually recur. ${ }^{29-33}$ Preservation of the uppermost part of the spleen vascularized only by the splenogastric vessels maintains splenic function without enlargement of the organ. ${ }^{21,34}$

In trauma, the spleen is almost always normal and there is no reason to remove this important organ. The multiple complications of the asplenic condition, including severe sepsis and precocious death are well established in the literature. ${ }^{35,36}$ In order to prevent such adverse events, nonoperative management and surgical procedures that preserve the spleen are routinely performed at most of advanced emergency services. ${ }^{37,38}$ Injuries to the splenic pedicle have challenged both non operative management and conservative operations. In these cases, we have successfully performed subtotal splenectomy, preserving the upper splenic pole supplied only by the splenogastric vessels.

Traditionally, distal pancreatectomy has included total splenectomy. ${ }^{40,41}$ Preservation of the spleen after ligation of its pedicle and maintenance of its main branches have been proposed in the literature. ${ }^{40-44}$ However, when it is not possible to preserve the splenic pedicle or its major branches, the surgeon may still preserve the upper pole supplied by the splenogastric vessels. ${ }^{45}$

According to published reports, the presence of splenomegaly in children and teenagers leads to retarded of growth and late sexual development, and therefore total splenectomy is frequently indicated. ${ }^{46}$ However, in our experience, subtotal splenectomy is sufficient to induce normal growth. ${ }^{47}$ Patients who were operated by us using this procedure reached normal somatic and sexual development in less than two years.

Another indication for total splenectomy is leukemia and lymphomas that are hardly controlled by chemotherapeutic drugs. Even in these cases, subtotal splenectomy is a better option due to the maintenance of the splenic defense capa- bilities without the adversities of splenomegaly. ${ }^{48}$

Vascular thrombosis and splenic malformations may provoke severe pain that does not respond to regular analgesic drugs. In these cases, removal of the spleen is indicated. To avoid the complications of the asplenic condition, we have performed laparoscopic subtotal splenectomy. This operation preserves the upper splenic pole with its proper vessels that prevent the effects of vascular pedicle thrombosis. ${ }^{49,50}$

The present paper describes the late follow up of 86 patients that are a subpopulation of the more than 200 patients who underwent subtotal splenectomy during the past 20 years at our institution.

\section{METHODS}

We assessed 86 patients who had undergone subtotal splenectomy (Figure 1) from 1 to 20 years previously for one of the following conditions: portal hypertension due to schistosomiasis with previous variceal bleedings $(n=43)$, trauma $(n=31)$ Gaucher's disease $(n=4)$, myeloid hepatosplenomegaly due to myelofibrosis $(n=3)$, splenomegalic retarded growth and sexual development $(n=2)$, severe pain caused by splenic ischemia $(\mathrm{n}=2)$ and cystadenoma of the pancreatic tail $(n=1)$. Other patients who had undergone the procedure refused to undergo the exams or did not return and were excluded from the present investigation. There were 55 men and 31 women in this study group. Their ages at the time of this study ranged from 17 to 81 $(44.4 \pm 18.8)$ years at the time of the present study.

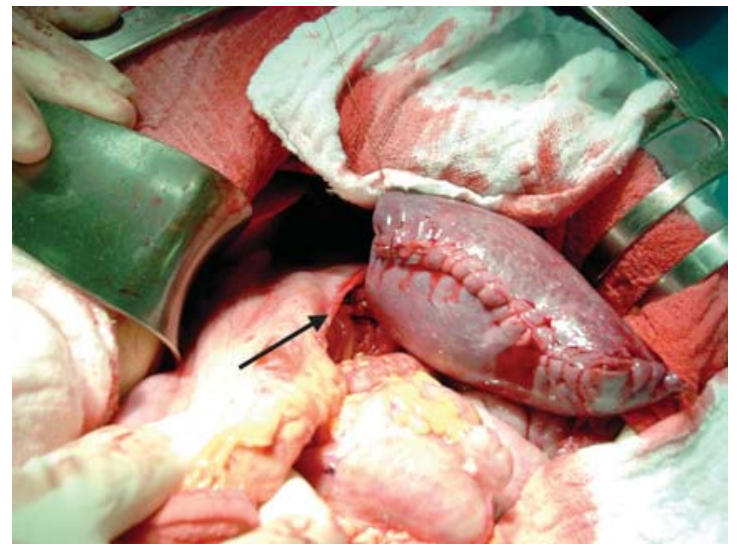

Figure 1 - Surgical aspect of subtotal splenectomy performed in a patient with portal hypertension. Observe the splenogastric vessels (arrow)

In addition to answering questions related to their disease, operation and postoperative period the patients underwent complete physical examination. Complementary exams included laboratory hematological and immunological (IgM, $\operatorname{Ig} \mathrm{A}, \mathrm{IgG}$, and active $\mathrm{B}$ and $\mathrm{T}$ lymphocytes) evaluation, upper GI endoscopy, abdominal ultrasonography, abdominal CT scan and splenic scintigraphy with ${ }^{99 \mathrm{~m}} \mathrm{Tc}$ sulfur colloid. 


\section{RESULTS}

All patients were satisfied with the results of the operation. They had no severe complication in the postoperative period. Episodes of fever (higher than $37.5^{\circ} \mathrm{C}$ ) were confirmed by 34 patients, even in the late postoperative period. These episodes were not related to signs of infection. Two patients were diagnosed with pneumonia in the postoperative period: one had been treated for portal hypertension and the other for myeloid hepatosplenomegaly. Both were successfully treated with antibiotics.

At physical examination following surgery, discrete (n $=8)$ or moderate $(n=2)$ ascites was found in 10 patients with portal hypertension who underwent external portal variceal disconnection. There was no evidence of hepatic or renal disturbances among these patients.

Six patients had supraumbilical median incisional hernias.

Hepatomegaly at the level of the right rib frame was found during physical examination of patients with myeloid hepatomegaly. Patients with Gaucher's disease had a palpable liver at 3 to $5 \mathrm{~cm}$ below the rib cage.

The hematological exam revealed a red cell count ranging from 4.0 to $5.6 \times 10^{6} / \mu \mathrm{l}$. The white cell count ranged between 3400 and $47000 / \mu$ l. Higher values were observed in patients with myelofibrosis. None of these patients had septic manifestations. In the preoperative period, the white cell count ranged from 1100 to $9400 / \mu$, with lower values in patients with portal hypertension. Howell-Jolly bodies, characteristic of asplenia, were not found in this series.

Platelets levels ranged from $135 \times 10^{3}$ to $430 \times 10^{3} / \mu \mathrm{l}$ except for two patients, one with portal hypertension (2055 $x 10^{6}$ ) and the other with myeloid hepatosplenomegaly $\left(2142 \times 10^{6}\right)$. Neither patient presented signs of coagulopathy in the postoperative period. Before the operation, the number of platelets ranged between 18 and 191 $\mathrm{x} 10^{3} / \mu \mathrm{l}$, with not clinical abnormalities.

Postoperative prothrombin times were $64 \%$ to $100 \%$ of reference values. However, in the preoperative period, the prothrombin time in patients with portal hypertension were 41 $\%$ to $79 \%$ of reference time without clinical manifestations.

The immunological pattern showed normal level of immunoglobulins in all patients. IgM ranged between 82 and $235 \mathrm{mg} / 100 \mathrm{ml}, \mathrm{IgA}$ from 141 to $604 \mathrm{mg} / 100 \mathrm{ml}$, and $\mathrm{IgG}$ from 1000 to $2314 \mathrm{mg} / 100 \mathrm{ml}$. The levels of lymphocytes were normal in all patients. Active B lymphocytes levels ranged from 11 to $19 / \mathrm{mm}^{3}$, and $\mathrm{T}$ lymphocytes levels from 23 to $52 / \mathrm{mm}^{3}$.

Endoscopy revealed esophageal varices in 33 patients and gastric varices in 12 patients who had undergone the treatment for portal hypertension. These varices were of smaller than those found in the preoperative period. No signs sug- gesting bleeding risk were found in any of these patients.

The ultrasound examination showed splenic remnant ranging from 2.9 to 18.1 centimeters in 30 patients. The portal vein revealed thrombosis of the left branch in 10 patients, with no clinical manifestations. CT scans showed the splenic upper pole stump supplied by the splenogastric vessels (Figure 2). Scintigraphic images of the splenic remnants were positive in 54 cases (Figure 3). Twelve of the patients did not present for the splenic scintigraphic image and twenty patients did not receive authorization for this exam.

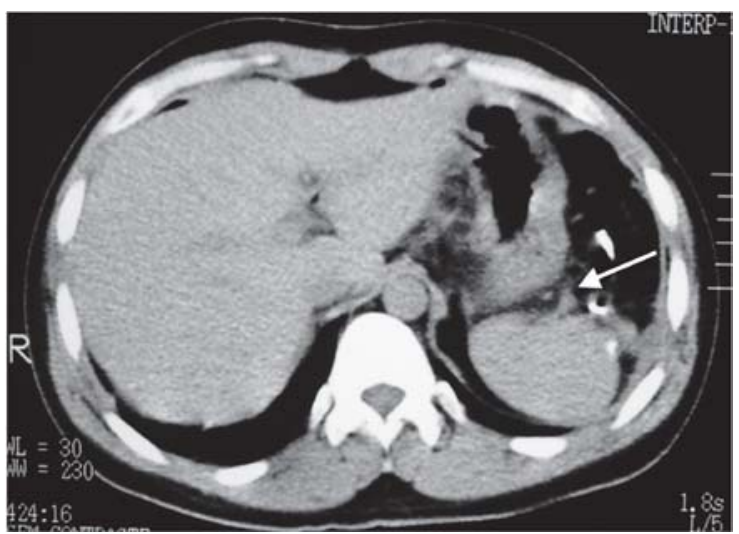

Figure 2 - Tomographic image of splenic remnant during the late postoperative periods following subtotal splenectomy for splenic ischemia. Observe the splenogastric vessels (arrow)

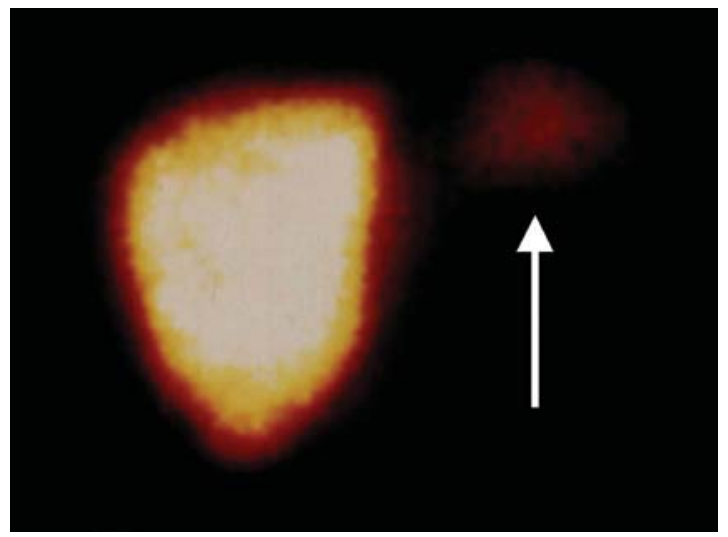

Figure 3 - Scintigraphic images (using ${ }^{99 \mathrm{~m}} \mathrm{Tc}$ sulfur colloid) of a splenic remnant (arrow) after subtotal splenectomy for portal hypertension

\section{DISCUSSION}

All patients who underwent subtotal splenectomy are registered in our hospital, but unfortunately we could not contact more than $40 \%$ of them. This difficulty is very common in Brazil because of widespread population migration. On the other hand, when the patients develop complication following the surgical procedure, they do return to the hospital of origin.

The outcome for patients who underwent subtotal splenectomy in the present study was favorable in various 
aspects. Previously, we verified that postsplenectomy infection is very rare in adults undergoing surgery for portal hypertension due to schistosomiasis ${ }^{13,51}$ However some patients presented with fever episodes without immune deficiency. ${ }^{13}$ Even though postsplenectomy fever is frequently reported in the literature, the exact mechanism is not completely understood. ${ }^{52,53}$ Some of our patients presented such episodes of fever until the late postoperative period. Episodes of fever were not considered to be a problem for the patients in the present study. Pneumonia was the only severe postoperative infection and had a benign course.

Ascites is a frequent finding in the early postoperative period of patients with portal hypertension due to schistosomiasis. ${ }^{13}$ Some patients may persist with this complication for longer periods of time. Control with diuretics is the therapeutic regimen of choice and was employed with our patients; this complication did not represent a major problem.

In this study we describe incisional hernias due to failure of the supraumbilical median incision closure. The care not to damage the veins of the hepatic round ligament played an important role in the development of this complication. The development of these hernias led us to change the operative approach to a left medial paramedian incision. During the last 14 years, using this approach, we have not had major incisional complications.

All patients with myeloid hepatosplenomegaly had enlargement of the liver during the early postoperative period. However, after 6 months, this organ reduced its size. Reportedly, the enlargement of the liver is one of the most severe complications after total splenectomy in patients with this disorder. ${ }^{27-30}$ Lethal hemorrhages and an extreme discomfort may occur in such circumstances. We did not find reports in the literature of a significant hepatic reduction. In our patients, livers, that increased in size by 12 to 14 centimeters immediately after the subtotal splenectomy are now palpable at the level of rib cage. We believe that partial preservation of the spleen may be involved in this observation, therefore the finding should be better evaluated.

Leukocytosis and thrombocytosis of the splenectomized patients have not been well explained in the literature. The absence of clinical manifestations indicates that this is a benign condition that should not be called hypersplenism, which refers to a severe disorder of the spleen. ${ }^{54}$

A frequent complication for patients with Gaucher's disease undergoing total splenectomy is severe bone pain and frequent fractures. ${ }^{16,19,20}$ Hepatic enlargement with functional compromise may also occur. Our patients presented no bone complaints and their liver enlargement was moderate.

In portal hypertension due to schistosomiasis, the prothrombin time is almost always under $70 \%$ of the refer- ence time. This is not well understood, but it does not mean coagulopathy. ${ }^{54}$ After subtotal splenectomy, all patients increased prothrombin time, in presence of remnant of splenic tissue.

Esophageal and gastric varices of patients with portal hypertension rarely disappear after surgical treatment. It is of the utmost importance to relieve internal variceal pressure. The complete absence of late postoperative bleedings confirms the efficacy of our procedures. Partial splenectomy with preservation of the splenic pedicle for the treatment of portal hypertension due to schistosomiasis has been published previously. ${ }^{55,56}$ However, the reported results were not as good as those obtained in our study, probably due to the adverse effects induced by the maintenance of the splenic vascular pedicle.

Partial splenectomy with preservation of the splenic pedicle, usually results in splenic remnant enlargement provoking abdominal discomfort especially in patients with portal hypertension, Gaucher's disease or myeloid hepatosplenomegaly. ${ }^{20,31,32,55}$ This symptoms by itself was an indication for surgery in the present study. The splenogastric vessels maintain the vitality of the upper pole. However, these vessels are incapable of inducing enlargement of the organ or blood supply to an enlarged spleen. ${ }^{49}$ Nevertheless, the splenic stump maintains the functions of the organ.

Clinical, laboratory and scintigraphic studies showed that the function of all splenic remnants. Further improvement of splenic function along with time was observed both experimentally and clinically in the present investigation. The absence of splenic images in some scintigraphies may be explained by failures of the method, since hematologic and immunologic exams did not show signs of asplenic process. Reportedly, inadequate tomographic and scintigraphic images may occur in $5 \%$ to $30 \%$ of these tests. 57-59 The factors that produce this failure in imaging have not yet been established. ${ }^{60}$

In conclusion, the 20 years of follow-up of patients undergoing subtotal splenectomy have shown that this procedure should be considered for the treatment of trauma, portal hypertension, myeloid hepatosplenomegaly, Gaucher's disease splenomegalic retarded growth and sexual development due to splenomegaly, severe pain due to splenic ischemia, chronic leukemia, lymphomas and surgical disorders of the distal part of the pancreas. This procedure may be performed by laparotomy or laparoscopy and seems to be a safe to treat conditions involving the spleen. The functions of the splenic remnants are preserved during long periods of time. Further studies with larger number of cases should be performed to further evaluate this therapeutic alternative. 


\section{ACKNOWLEDGMENT}

The authors thank Professor Dr. Dulmar Garcia de Carvalho for endoscopic procedures, Professor Dr. Carlos Jorge Rodrigues Simal, for the scintigraphies, Dr. Rogério
Augusto Pinto da Silva for the ultrsonographic studies.

The authors are grateful to Conselho Nacional de Desenvolvimento Científico e Tecnológico (CNPq) and to Fundação de Assistência à Pesquisa de Minas Gerais (FAPEMIG) and for the financial supports.

\section{RESUMO}

Petroianu A, Resende V, Silva RG da. Acompanhamento pós-operatório tardio de pacientes submetidos a esplenectomia subtotal. Clinics. 2005;60(6):473-8.

OBJETIVO: Durante 21 anos, realizamos mais de 200 esplenectomias subtotais para tratar diferentes condições patológicas. É fundamental conhecer os resultados pós-operatórios desse procedimento.

MÉTODO: Todos os pacientes submetidos a esplenectomia subtotal foram convidados para serem submetidos a revisão. Pudemos reunir 86 pacientes operados em um período de um a vinte anos por hipertensão porta esquistossomática com sangramento prévio pelas varizes $(n=43)$, trauma $(n=31)$, doença de Gaucher $(n=4)$, hepatoesplenomegalia mielóide devido a mielofibrose $(n=3)$, retardo de desenvolvimento somático e sexual esplenomegálico $(n=2)$, dor intensa por isquemia esplênica $(n=2)$ e cistoadenoma corpocaudal pancreático $(n=1)$. Os paci- entes foram submetidos a exame hematológico, avaliação imunológica, ultra-som, tomografia computadorizada, cintilografia e endoscopia digestiva alta.

RESULTADOS: Aumento do número de leucócitos e plaquetas foram a única alteração hematológica encontrada. Não foram constatados distúrbios imunológicos. Varizes esofágicas ainda estavam presentes em pacientes operados de hipertensão porta, porém sem ressangramento. $\mathrm{O}$ ultra-som, a tomografia computadorizada e a cintilografia confirmaram a presença do remanescente esplênico funcionante, sem mudanças em seu tamanho.

CONCLUSÃO: A esplenectomia subtotal parece ser um procedimento seguro e pode seu útil para tratar condições nas quais o baço estiver envolvido.

PALAVRAS-CHAVE: Esplenectomia parcial. Esplenectomia subtotal. Baço. Conservação esplênica. Pós-operatório.

\section{REFERENCES}

1. Petroianu A. Esplenectomia subtotal e anastomose esplenorrenal proximal para tratamento da hipertensão portal. Rev Bras Cir. 1983;73:101-104.

2. Petroianu A, Ferreira VLM, Barbosa AJA. Morphology and viability of the spleen after subtotal splenectomy. Braz J Med Biol Res. 1989;22:491-495.

3. Petroianu A, Barbosa AJA. Quantitative studies on the macrophage phagocytosis in whole spleen and in the remnant of subtotal splenectomy. Med Sci Res. 1991;19:373-375.

4. Petroianu A, Simal CJR, Barbosa AJA. Splenic macrophage phagocytic function after subtotal splenectomy in dog. Med Sci Res. 1992;20:127128.

5. Petroianu A, Simal CJR, Barbosa AJA. Impairment of phagocytosis by mammalian splenic macrophages by $99 \mathrm{mTc}$ sulphur colloid. Med Sci Res. 1992;20:847-849.

6. Petroianu A. Splenic viability after segmental devascularization. Rev Paul Med. 1992; 110: 39-41.

7. Petroianu A, Simal, CJR. Shifts of the reticuloendothelial system uptake pattern induced by carbon colloid. Med Sci Res. 1993;21:311-312.

8. Petroianu A, Simal CJR, Barbosa AJA. Assessment of phagocytic function in remnants of subtotal splenectomy and in autologous spleen implantation. Med Sci Res. 1993;21:715-717.
9. Petroianu A, Berindoague RN. Laparoscopic subtotal splenectomy. Minerva Chir. 2004;59:501-505.

10. Petroianu A. Treatment of portal hypertension by subtotal splenectomy and central splenorenal shunt. Postgrad Med J 1988;64:38-41.

11. Petroianu A, Petroianu LPG. A twelve-year-follow-up of subtotal splenectomy and central splenorenal shunt for treatment of schistosomatic portal hypertension. Folha Méd. 1998;116:107-109.

12. Petroianu A. - Avaliação imaginológica da esplenectomia subtotal e anastomose esplenorrenal centralizada para o tratamento da hipertensão portal esquistossomática. Rev Méd Minas Gerais. 1993;3:106-108.

13. Araujo ID, Pinto PMM, Diniz GV, Petroianu A. Evolução pós-operatória tardia de pacientes esplenectomizados e portadores de derivação portossistêmica. Rev Bras Méd. 1991;48:271-274.

14. Petroianu A. Subtotal splenectomy and portal-variceal disconnection in the treatment of portal hypertension. Can J Surg. 1993;36:251-254.

15. Petroianu A. Subtotal splenectomy in Gaucher's disease. Eur J Surg. 1996;162:511-513.

16. Fleshner PR, Astion DJ, Ludman MD. Gaucher disease. J Pediat Surg. 1989;24:610-612.

17. Govrin-Yehudain J, Bar-Maor JA. Partial splenectomy in Gaucher's disease. Israel Med Sci. 1980;16:665-668. 
18. Morgenstern L, Phillips EH, Fermelia D et al. Near-total splenectomy for massive splenomegaly due to Gaucher disease. Mount Sinai J Med. 1986;53:501-505.

19. Kyllerman M, Conradi N, Mansson JE. Rapidly progressive type III Gaucher disease. Acta Pediat Scand. 1990;79:448-453.

20. Fleshner PR, Aufses AHJR, Grabowski GA. A 27-year experience with splenectomy for Gaucher's disease. Am J Surg. 1991;161:69-75.

21. Petroianu A, Silva RG, Simal CJR. Late postoperative follow-up of patients submitted to subtotal splenectomy. Am Surg. 1997;63:735-740.

22. Petroianu A. Esplenectomia subtotal preservando o pólo superior suprido pelos vasos esplenogástricos. Rev Col Bras Cir. 1994;21:21-26.

23. Smith RE, Chelmowiski MK, Szabo EJ. Myelofibrosis. Am J Hematol. 1988;29:174-180.

24. Järvinen H, Kivilaakso E, Ikkala E. Splenectomy for myelofibrosis. Ann Clin Res. 1982;14:66-71.

25. Saad GMP, Almeida TV. Mielofibrose idiopática. Rev Paul Méd. 1991; 109:47-50.

26. López-Guillermo A, Cervantes F, Bruguera M, Pereira A, Feliu E, Rozman C. Liver dysfunction following splenectomy in idiopathic myelofibrosis. Acta Haematol. 1991;85:184-188.

27. Jacobs P. - Splenectomy and myelofibrosis. South Afr Med J. 1976;50:550-1.

28. Benbassat J, Penchas S, Ligumski M. Splenectomy in patients with agnogenic myeloid metaplasia. Br J Haematol. 1979;42:207-214.

29. Cabot EB, Brennan MF, Rosenthal DS. Splenectomy in myeloid metaplasia. Ann Surg. 1978;187:24-30.

30. Towell BL, Levine SP. Massive hepatomegaly following splenectomy for myeloid metaplasia. Am J Med. 1987;82:371-375.

31. Morgenstern L, Kahn FH, Weinstein IM. Subtotal splenectomy in myelofibrosis. Surgery. 1966;60:336-339.

32. Campos-Christo M. Partial splenectomies in hematologic diseases. Chir Gastroenterol. 1993;9(suppl 2):23-29.

33. Campos Christo MB, Didio JLA. Anatomical and surgical aspects of splenic segmentectomies. Ann Anat. 1997;179:461-474.

34. Petroianu A. Subtotal splenectomy for treatment of patients with myelofibrosis and myeloid metaplasia. Int Surg. 1996;81:177-179.

35. Offenbartl K. Postsplenectomy sepsis. Bull Lund Univ. 1985;56:4-65.

36. Pimpl W, Dapunt O, Kaindl H. Incidence of septic and thromboembolicrelated deaths after splenectomy in adults. Br J Surg. 1989;76:517-521.

37. Upadhyaya P. Conservative management of splenic trauma. Pediatr Surg Int. 2003;19:617-627.

38. Poulin EC, Thibault C, Côteaux JG, Côté G. Partial laparoscopic splenectomy for trauma. Surg Laparosc Endosc. 1995;5:306-310.

39. Resende V, Petroianu A. Subtotal splenectomy for treatment of severe splenic injuries. J Trauma. 1998;44:933-935.

40. Cooper MJ, Williamson RCN. Conservative pancreatectomy Br J Surg. 1985;72:801-803.
41. Richardson DQ, Scott-Conner CEH. Distal pancreatectomy with and without splenectomy. Am Surg. 1989;55:21-25.

42. Dawson DL, Scott-Conner CEH. Distal pancreatectomy with splenic preservation. J Trauma. 1986;26:1142-1145.

43. Warshaw AL. Conservation of the spleen with distal pancreatectomy. Arch Surg. 1988;123:550-553.

44. Schein M, Freinkel W, D'Egidio A. Splenic conservation in distal pancreatic injury. J Trauma. 1991;31: 431.

45. Petroianu A. Treatment of cystadenoma of the pancreatic tail by distal pancreatectomy and subtotal splenectomy. Dig Surg. 1995;12:259-261.

46. Chen Y Dabovic B, Colarossi C. Growth retardation as spleen and thymus involution. J Cell Physiol. 2003;196:319-325.

47. Petroianu A. Subtotal splenectomy for treatment of retarded growth and sexual development. Minerva Chir. 2003;58:413-414.

48. Petroianu A. Subtotal splenectomy for the treatment of chronic lymphocytic leukemia. Ann Hematol. 2003;82:708-709.

49. Petroianu A, Petroianu S. Anatomy of splenogastric vessels in patients with schistosomal portal hypertension. Clin Anat. 1994;7:80-83.

50. Petroianu A, Andrade MAC, Neto RB. Laparoscopic subtotal splenectomy. Aust New Zeal J Surg. 2005; in press.

51. Petroianu A, Antunes LJ. Immune profiles in hepatosplenic schistosomiasis mansoni after surgical treatments. J Int Med Res. 1998;26:43-49.

52. Cooper MJ, Williamson RCN. Splenectomy. Br J Surg. 1984;71:173180 .

53. Alves CAP, Rebouças G. Esplenectomia na esquistossomose hépatoesplênica. Hospital. 1964;66:899-905.

54. Petroianu A, Oliveira AE, Alberti LR. "Hypersplenism" in schistosomatic portal hypertension. Arch Med Res. 2005;36:496-501.

55. Kamel R, Dunn MA. Segmental splenectomy in schistosomiasis. Br J Surg. 1982;69:311-313.

56. Cleva R, Saad WA, Herman P, Pugliese V, Zilberstein B, Laudanna AA, et al. Portal hyperflow in patients with hepatosplenic mansonic schistosomiasis. Rev Hosp Clin Fac Med S Paulo. 2004;59:10-14.

57. Hermann HJ, Winkel K. Scintigraphy of the spleen. Lymphology. 1977;10:115-119.

58. Sapucahy MV, Faintuch J, Bresciani CJC, Bertevello PL, Habr-Gama A, Gama-Rodrigues JJ. Laparoscopic versus opern splenectomy in the management of hematologic diseases. Rev Hosp Clin Fac Med S Paulo. 2003;58:243-249.

59. Corazza GR, Tarozzi C, Vaira D. Return of splenic function after splenectomy. Br Med J. 1984;289:861-866.

60. Petroianu A, Corsetti RA, Alberti LR. The effect of the presence of muscle tissue in a bone healing site. Rev Hosp Clin Fac Med S Paulo. 2004;59:193-197. 